\section{Chemical immobilization of free-living capybaras (Hydrochoerus hydrochaeris) using ketamine-dexmedetomidine combination and a remote drug delivery system}

\author{
Imobilização química de capivaras de vida livre \\ (Hydrochoerus hydrochaeris) usando a combinação \\ cetamina-dexmedetomidina e um sistema de administração \\ remota de medicamentos
}

\begin{abstract}
Derek Rosenfield' (D), Mario Antonio Ferraro² (D), Claudia Igayara Souza ${ }^{3}$ (D) , Silvia Renata Gaigo Cortopassi ${ }^{4}$ (D) Cristiane Schilbach Pizzutto 5

'Veterinary, DSc. Departamento de Reprodução Animal Silvestres, Faculdade de Medicina Veterinária e Zootecnia, Universidade de São Paulo - USP, São Paulo, SP, Brasil

Veterinary, MSc. Departamento de Cirurgia, Faculdade de Medicina Veterinária e Zootecnia, Universidade de São Paulo - USP, São Paulo, SP, Brasil

${ }^{3}$ Veterinary, MSc. Hospital Veterinária, Zoológico Municipal de Guarulhos, Guarulhos, SP, Brasil

${ }^{4}$ Veterinary, PhD. Departamento de Cirurgia, Faculdade de Medicina Veterinária e Zootecnia, Universidade de São Paulo - USP, São Paulo, SP, Brasil

${ }^{5}$ Veterinary, PhD. Departamento de Reprodução Animal Silvestres, Faculdade de Medicina Veterinária eZootecnia, Universidade de São Paulo - USP, São Paulo, SP, Brasil
\end{abstract}

\begin{abstract}
Capturing wild capybaras for scientific projects, population control or medical interventions is a growing necessity. With this study, weintended to evaluate the association Ketamine/Dexmedetomidine (KD) as a reversible chemical restraint protocol in free-ranging synanthropic capybaras, seeking enhanced anesthetic and recovery characteristics while testing a specialized remote drug delivery system (RDDS). For this purpose, 18 adult capybaras (eight males, ten females) with a mean bodyweight of $67.3 \pm 9.45 \mathrm{~kg}$ were used. Prior to chemical restraint, the animals were physically confined, subsequently darted intramuscularly (IM) with $9.9 \mathrm{mg} / \mathrm{kg}$ ketamine with $0.0005 \mathrm{mg} / \mathrm{kg}$ dexmedetomidine. Post-intervention, $0.005 \mathrm{mg} / \mathrm{kg}$ atipamezole, administered IM, was used ( $\mathrm{n}=5$ ) as a reversal agent (RA). Anesthetic effects were classified and recorded as LP1-latency period one (first observed effects). LP2 - latency period two, lateral recumbency, plus apt-time (able to handle animal). R1 - total recovery period one, no RA. R2, subdivided in R2a - partial recovery period one, ambulant position/but with incoordination, and R2b - partial recovery period two, time to full recovery (with RA). Vital signs were recorded at a 15-minute interval. Results: Induction time LP1: $3 \pm 1 \mathrm{~min}$ and LP2: $10 \pm 2 \mathrm{~min}$. Procedure duration: $53 \pm 25 \mathrm{~min}$. (sedated). Recovery time R1: $55 \pm 15 \mathrm{~min}$. R2a: $18 \mathrm{~min}$., RA2b: $\pm 45 \mathrm{~min}$., total recovery time (R2a/b): $67 \pm 13.85 \mathrm{~min}$. Conclusion: KD association provided excellent sedation, analgesia, and muscle relaxation, with a relative short induction time. Used RA did not shorten total recovery time significantly. Adverse effects such as the risk of acute cecal tympany, due to the lack of pre-anesthetic fasting, concurrent to collateral effects of injectable and volatile anesthetics on the motility of the digestive tract, and potential for induced bradycardia/hyperthermia warrant extra caution. The employed RDDS performed satisfactorily under field conditions.
\end{abstract}

Keywords: RDDS, wildlife chemical restraint, atipamezole, capybara.

\section{Resumo}

Capturar capivaras selvagens para projetos científicos, controle populacional ou intervenções médicas éuma necessidade crescente. Com esteestudo, pretendemos avaliar uma associação de cetamina/dexmedetomidina como uma contenção química reversível em capivaras sinantrópicas de vida livre, buscando melhorar as características anestésicas e de recuperação e, ao mesmo tempo, testar um sistema remoto de liberação controlada demedicamentos (RDDS). Para tanto, foram utilizadas18 capivaras adultas (machosn = oito; fêmeas $\mathrm{n}$ = dez) com peso médio de $67.3 \pm 9.45 \mathrm{~kg}$. Antes da contenção química, elas foram fisicamente confinadas, e receberam dardos por via intramuscular com $9 \mathrm{mg} / \mathrm{kg}$ de cetamina e $0.005 \mathrm{mg} / \mathrm{kg}$ de dexmedetomidina. Após a intervenção, $0.005 \mathrm{mg} / \mathrm{kg}$ de atipamezol via IM (n=5), foram utilizados como agente de reversão (RA).

\section{BJ $\mathrm{M}$}

Brazilian Journal of Veterinary Medicine

p-ISSN 0100-2430

e-ISSN 2527-2179

○

How to cite: Rosenfield, D., Ferraro, M.A., Souza, C.I., Cortopassi, S.R.G., Pizzutto, C.S. (2020). Chemical immobilization of free-living capybaras (Hydrochoerus hydrochaeris) using ketamine-dexmedetomidine combination and a remote drug delivery system. Brazilian Journal of Veterinary Medicine, 42, e107220. doi: 10.29374/2527-2179.bjvm107220

Financial support: FAPESP, Pneu-Dart, Inc. Conflict of interests: No conflict of interests declared concerning the publication of this article.

Received: October 10, 2019

Accepted: December 09, 2019

The study was carried out at Hydrochoerus hydrochaeris, at the Raia Olímpica, Departamento de Reprodução Animal Silvestres, Universidade de São Paulo, São Paulo, SP, Brasil

\title{
*Correspondence
}

Derek Rosenfield

Departamento de Reprodução Animal, Universidade de São Paulo - USP

Campus Cidade Universitária

CEP 05508-270 - São Paulo (SP), Brasil

E-mail:dro@usp.br

Copyright Rosenfield et al. This is an Open Access article distributed under the terms of the Creative Commons Attribution Non-Commercial License which permits unrestricted non-commercial use, distribution, and reproduction in any medium provided the original work is properly cited. 
Os efeitos anestésicos foram classificados e registrados como: LP1 - período de latência um (primeiros efeitos observados); LP2 - período de recuperação total, decúbito lateral (somado ao tempo apto para manipular o animal); R1- período de recuperação total (sem uso de RA); R2, subdividido em R2a - período recuperação parcial um, posição para deambular, mas ainda com incoordenação, e R2b - período recuperação parcial dois, até recuperação total (uso de RA). Os sinais vitais foram registrados em um intervalo de 15 minutos. Resultados:LPI: $3 \pm 1$ mineLPII: $10 \pm 2$ min. Duração do procedimento: $53 \pm 25$ min. (sedados). Tempo derecuperação R1:55 \pm 15 min.; R2a 18 min., mais R2b \pm 45 min. Tempo recuperação total: (R2a/b): 67 \pm 13.85 min. Concluiu-se, assim, quea associação cetamina/dexmedetomidina teveum desempenho satisfatório, proporcionando sedação e analgesia eficazes eperíodos relativamente curtos de latência. A RAutilizadanão reduziu significativamente o tempo total de recuperação. Os efeitos adversos, como o risco de timpanismo agudo no cécum, devido à falta de jejum pré-anestésico, concomitante aos efeitos colaterais dos anestésicos injetáveis e voláteis sobre a motilidade do trato digestivo, e bradicardia/ hipertermia induzida, exigem cautela extra. O RDDS (dardos) utilizado possibilitou a administração confiável dos medicamentos em condições de campo.

Palavras-chave: dardos, contenção química, atipamezol, capivara.

\section{Introduction}

Capybaras (Hydrochoerus hydrochaeris) are the world's largest living rodent, reaching a bodyweight of $\pm 55 \mathrm{~kg}$ in their natural habitats (Moreira, 2013), whereas synanthropic members (groups living in or nearby urban, and agricultural areas) may reach weights in excess of 100kg (pers. comm. 2018)

As semi-aquatic animals, using water for protection, thermoregulation, and reproduction, they always stay in very close proximity to water. In consequence, making capybara capture notoriously challenging, as any chemical restraint demands a series of precautions. For example, the physical confinement prior to anesthesia in order to prevent darted animals from escaping into the water, which would inevitably bring about death by drowning (Herrera \& Macdonald, 1989; Mones \& Ojasti, 1986; Rosenfield et al., 2019a,b; Salas et al., 2004).

As part of an ongoing population control research on synanthropic capybaras, in a continuous effort of finding a safe and fast-acting anesthetic protocol for free-ranging capybaras, we compared the classic combination of ketamine-xylazine with a more novel combination of ketamine-dexmedetomidine.

Ketamine hydrochloride, besides its excellent analgesic properties, can be safely administered IM (intra-muscular), which allows for dart delivery. In addition to little adverse effects, such as respiratory - and cardiovascular depression, if used in adequate dosages. Making it one of the most studied and employed anesthetics for chemical restraint in a large variety of wildlife species (Cizauskas, 2008; Spinosa et al., 2011; West et al., 2007). Furthermore, Ketamine is most often associated with alpha-2 agonists, benzodiazepine, and opioids, or any combination thereof. A typical association used is ketamine with an alpha-2 agonist, like Xylazine hydrochloride, or the more novel and potent medetomidine and dexmedetomidine. In addition to its analgesic and muscle relaxing properties, one of its major advantages is reversible sedation by an $\alpha-2$ adrenergic antagonist, such as atipamezole, yohimbine or tolazoline(Spinosa et al., 2011; Wellington et al., 2013; West et al., 2007). However, alpha-2 agonists are known for some undesirable effects in the form of bradycardia and respiratory depression as well as peripheral vasoconstriction. Also, KX has shown a prolonged induction time, compared to KD in rodent species (Cruz et al., 1998; Wellington et al., 2013).

The objective of this project was to evaluate a ketamine/dexmedetomidine association as an alternative tranquilizer protocol in Hydrochoerus hydrochaeris, seeking a short time of action (latency period), little adverse effects, and faster recovery, including the use of atipamezole as a potential reversal agent. Additionally, we evaluated the use of a modern Remote Drug Delivery System and a blowgun.

\section{Methods and materials}

After the project approval by the University's Ethics Committee for Use of Animals in Research (CEUAVET: 9553260816) and the Brazilian Ministry of Environment (SISBio: 54634-2), 18 free-ranging, synanthropic (Hydrochoerus hydrochaeris), eight males and ten females, mean body weight $67.3 \pm$ SD 9.45, and an estimated age of three to five years.

The study was conducted at a large, man-made water pool, with trees and extended grass areas, used for water-based athletics. This pool resembles in its environmental condition the natural capybara habitats while allowing for constant observations (area approx. 2000m x 120m). 
The animals that participated in the study on population control, are considered synanthropic, as they invaded, from their natural habitats, via tributary river systems, into inner-city areas, until finally reaching the athletic pool area.

Although the animals were conditioned for herding, they would not allow being physically manipulated. In order to gather biometric data, ID marking, biomaterial collection, treatment, and to avoid serious bite-injuries, animals were first physically confined and subsequently sedated. Capturing started early morning, to minimize the hyperthermia in the animals.

Within the group, adult males and females were chosen for their role as principal breeders.

\section{RDDS Technology (Remote Drug Delivery System)}

After physical restraint, the animals were anesthetized using aCO2 dart projector (X-Caliber, Gauged CO2 Long Range Projector, Pneu-Dart Inc, Williamsport, PA, USA) and specialized darts with various volume capacities, as well as a needle length suitable for intramuscular injection (Type P, with tri-port, gel collar, cannula with $4.44 \mathrm{~cm}$ ). Specifically chosen for their advanced technologies such as: explosive charge to drivetheplunger forward to inject the drug load; agel collar, which, after reaching subcutaneous tissues would remain for an extended time, beforestarting to soften (due to body temperature), eventually detaching itself; a slow-inject technology, injecting the drug at a lower speed to potentially minimize further tissue damage, in additionally, the tri-port concept would deposit the drug over a much larger surface (Figure 1), augmenting the absorption rate, thus, shortening the latency period.

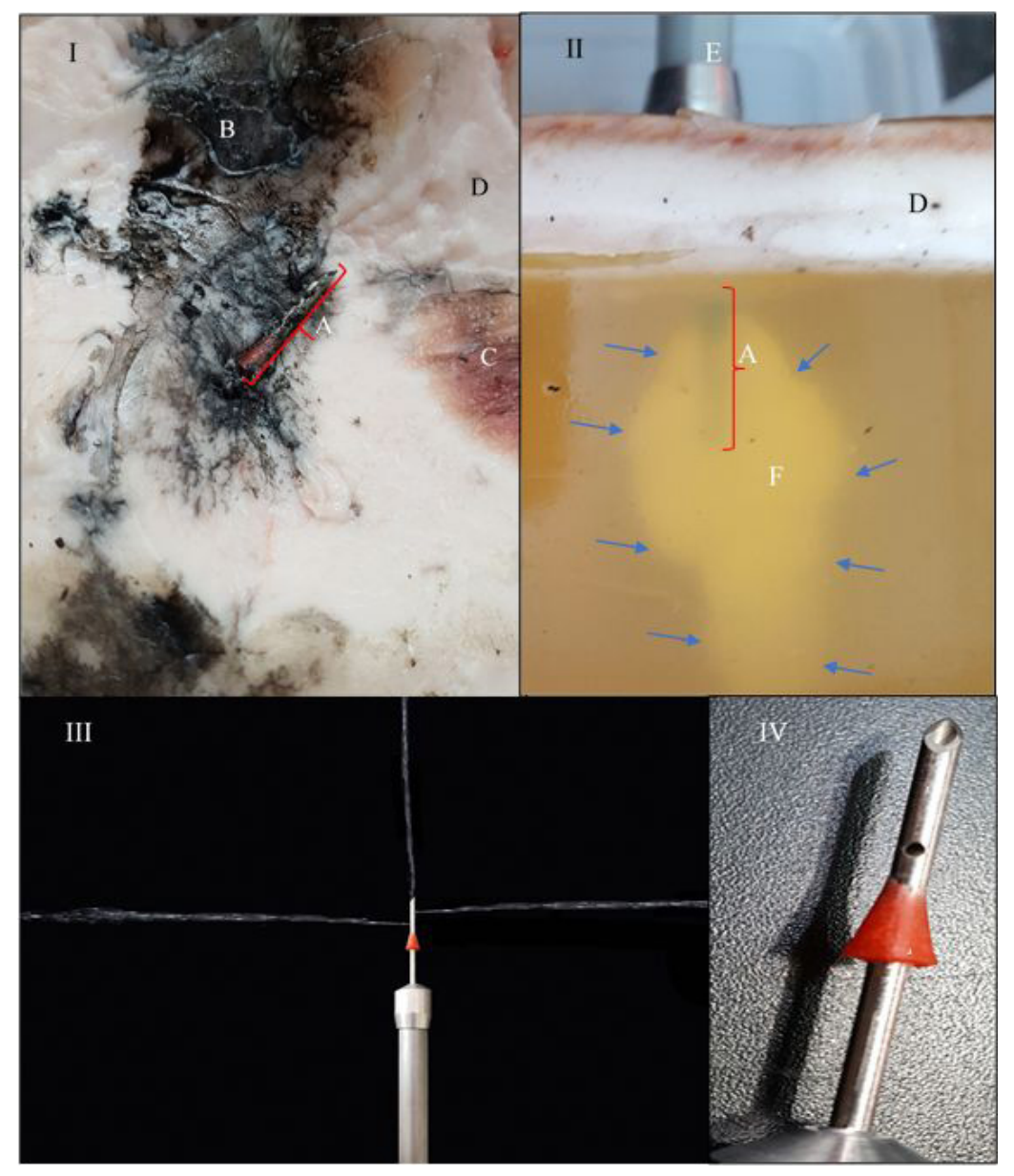

Figure 1. RDDS deposit quality. I) View of the ink-stained adipose layered side of a fresh pork hide, mounted on ballistic gel., depicting deployed dart with Tri-port effect .II) Pork hide, mounted on ballistic gel, in comparison, showing a deployed Single-port dart, with canula perforation through the adipose tissue, depositing the drug IM. Dart canula (red marker); Concentrated drug deposit (blue arrows). A) Dart canula with gel collar. B) Tri-port dispersed drug deposit (black ink) in adipose tissue layer. C) Start of muscular tissue layer. Red arrow: adequate dart canula length for IM injection. E) Dart. F) Single-port concentrated local drug deposit. III) Drug jet stream when forced through the Tri-port. IV) Tri-port and gel collar close-up. 
The darts were launched from various distances using a $\mathrm{CO} 2$ powered projector, ranging from a minimum of $5 \mathrm{~m}$ to $30 \mathrm{~m}$, and a blowgun, for a distance up to approximately $4 \mathrm{~m}$. In both applications, only hindlimb musculatures(M.bicepsfemoris, M. semitendinosus/semimembranosus) weretargeted.

Drug delivery quality was confirmed by removing any post-darting drug residue, which then was compared to the original loaded volume.

\section{Anesthetic protocol}

Before any intervention, time was invested to condition the animals, allowing for frequent capture, while minimizing associated stress. Target animals were identified (principal breeder) and physically restrained by herding them into large corrals (approx. $58 \mathrm{~m}^{2} ; 27 \mathrm{~m}$ circumference).

To minimize tissue damage during dart administration using the $\mathrm{CO} 2$ projector, the corral area allowed for a maximum distance to the target animal of about $9 \mathrm{~m}$.

For initial anesthetic dosage calculation, an estimated body weight of $70 \mathrm{~kg}$ was used for all animals.

KD protocol, Ketamine hydrochloride $100 \mathrm{mg} / \mathrm{ml}$ (Syntec, Brazil), injectable, dosage $9.9 \mathrm{mg} / \mathrm{kg}$ (6.93ml) and Dexmedetomidine hydrochloride $0.5 \mathrm{mg} / \mathrm{ml}$ (Dexdomitor, Zoetis, Brazil), injectable, dosage $0.0005 \mathrm{mg} / \mathrm{kg}(0.07 \mathrm{ml})$ combined as a single-dose and filled into a $7 \mathrm{ml}$ dart. After chemical restraint, a moistened cloth was placed over the eyes for ocular protection and to minimizing luminous stimuli.

\section{Evaluation of anesthetic effects}

In capybara, achieving recumbency does not mean the animal is ready to be handled, in fact, there is a potential of being bitten for several minutes after it would achieve a recumbent position. Therefore, the initial anesthetic effects were evaluated by measuring two latency periods:

- LP-I (onset of action), defined as the time from dart deployment to first observed incoordination, and

- LP-II, lateral recumbency/apt time, defined as the time from darting to a lateral lying position and the moment when the animal could be safely manipulated/transported.

- Duration of action, defined as the time of procedure initiation (post-LP-II) until the time when the animal is being returned to the corral for recovery.

- Full recovery time without reversal agent (R1): defined as the time from lateral recumbency to ambulation, free of any visible anesthetic effects (incoordination), at which time the animal could be safely released.

- Full recovery time with reversal agent (R2a): defined as the time from recumbent to ambulant position, and (R2b) ambulant animal, without observed incoordination, time of safe release.

Anesthetic depth was assessed and scored following the methods described by (Ferraro et al., 2019), performing different reflex tests, such as response to pupillary light reflex, palpebral reflex, corneal reflex, eyeball position, and muscle relaxation. Monitored surgical stimuli were used to evaluate antinociception effectiveness.

\section{Monitoring of physiological parameters}

The as normal described vital parameters in this study (N) are defined as observed vital signs not under the influence of anesthetic effects, in contrast to in literature commonly described physiological parameters, which are recorded during anesthesia.

\section{N - normal vital signs}

Recording vital signs of non-sedated animals was done by luring the conditioned animals into close distance, allowing to perform light physical examinations (Figure 2), including:

- Heart rate, direct thoracic auscultation

- Respiratory rate, direct thoracic auscultation, alternatively, observation of chest wall movements

- Body temperature, using an infrared thermometer (Digital Laser, Model KP-8005, Knup, Brazil) at a distance of $\pm 10 \mathrm{~cm}$ into the external acoustic meatus (ear canal).

Reported vital sign parameters of non-sedated animals were used as a base reference and compared to values UAE (under anesthetic effects). 


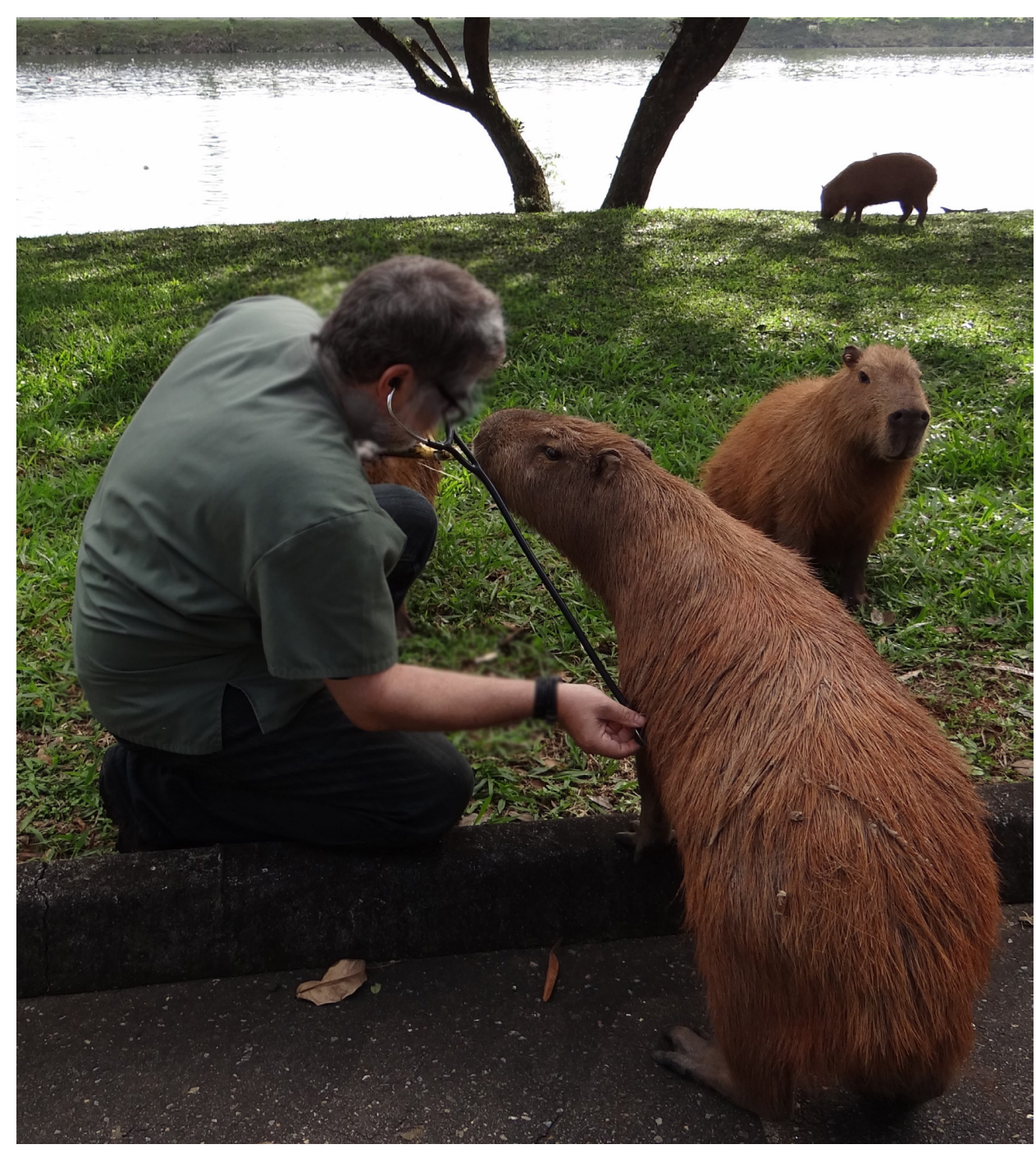

Figure 2. Monitoring normal vital signs (depicting heart frequency auscultation) during voluntary exam.

\section{Under Anesthetic Effect (UAE)}

While under sedation, vital physiological parameters were continuously monitored during none-invasive and semi-invasive procedures.

- Pulse

- Rectal temperature

- Blood-oxygen saturation was recorded using a veterinary pulse oximeter (ARSTN, China), placing the sensors inter-digitally, or on the tongue. Readings were taken in intervals of 15 minutes, supported by intermittent auscultation exams for

- Heart rate

- Respiratory frequency

- Peristalsis

During invasive procedures, heart frequency, respiratory rate, blood oxygen saturation, and rectal temperature were monitored using a DX 2022+ Multiparameter Monitor (Dixtal - Philips Healthcare, Brazil).

\section{Bodyweight ( $\mathrm{kg})$}

After sedation took effect, the animals were placed on a flex-stretcher and weighed on a digital hanging weighing scale (Mini Digital Crane Scale 300kg, Outmate, China). 


\section{Reversal agent}

After the animal was returned to the corral for anesthetic recovery, the alpha-2 agonist effects were reversed with atipamezole $5.0 \mathrm{mg} / \mathrm{mL}$ (Antisedan, Zoetis, Brazil), administered by hand-syringe, using a dosage equal 1:1 of the preceding dexmedetomidine dosage volume.

\section{Statistical analysis}

For statistical interpretation, comparing two groups, ANOVA, one-way analysis of variance (average \pm SD), Good Calculators, 2019, was used. Differences were considered as statistically significant when $\mathrm{p}<0.05$ (Goodcalculators, One-way ANOVA).

\section{Results}

\section{Projector versus blowgun}

After three initial failed attempts to use type-P dart with a blowgun (bounce-backs), the use of a blowgun was consequently suspended, to not further stress the animal. All darts launched with the X-Caliber $\mathrm{CO} 2$ projector delivered the drugs satisfactorily.

\section{Latency periods and recovery times}

Observed anesthetic effects/latency periods of ketamine/ dexmedetomidine association, and observed recovery times, with and without the use of a reversal agent, are represented in Table 1, and Figure 3-5.

Table 1. Latency period comparison.

\begin{tabular}{|c|c|c|c|c|}
\hline $\begin{array}{l}\text { Latency } \\
\text { period }\end{array}$ & Effects observed & $\begin{array}{l}\text { Time min. } \\
(\text { mean } \pm \text { SD) }\end{array}$ & $\begin{array}{l}\text { Time range } \\
\text { minutes }\end{array}$ & $\begin{array}{l}\text { Number of animals } \\
\text { (n) }\end{array}$ \\
\hline LP 1 & On set of drug action; 1st incoordination & $4 \pm 8.3$ & $3-6$ & $\mathrm{n}=18$ \\
\hline \multirow[t]{2}{*}{ LP 2} & Lateral recumbency, apt time to safe approach & $8 \pm 1.68$ & $6-12$ & $\mathrm{n}=18$ \\
\hline & Total latency period & $12 \pm 9.98$ & & \\
\hline $\begin{array}{l}\text { Anesthetic } \\
\text { Duration }\end{array}$ & Total time of procedures & $53 \pm 20.89$ & $53-96$ & $\mathrm{n}=18$ \\
\hline $\begin{array}{l}\text { Recovery } \\
\text { times }\end{array}$ & Effects observed & $\begin{array}{l}\text { Time min. } \\
(\text { mean } \pm \text { SD) }\end{array}$ & $\begin{array}{l}\text { Time range } \\
\text { minutes }\end{array}$ & $\begin{array}{l}\text { Number of animals } \\
\text { (n) }\end{array}$ \\
\hline \multirow[t]{2}{*}{$\begin{array}{l}\text { R1 } \\
\text { No reversal } \\
\text { agent }\end{array}$} & $\begin{array}{l}\text { Time from lateral recumbency to ambulant position. } \\
\text { No evidence of impairment of motor function } \\
\text { Safe to release }\end{array}$ & $67 \pm 13.85$ & $40-79$ & $n=13$ \\
\hline & Total time to recovery & $67 \pm 13.85$ & & \\
\hline $\begin{array}{l}\mathrm{R} 2 \mathrm{a} \\
\text { With reversal } \\
\text { agent }\end{array}$ & $\begin{array}{l}\text { Time from recumbency to ambulant position. } \\
\text { Disorientation/impairment of motor function }\end{array}$ & $18 \pm 15.60$ & $13-20$ & $n=5$ \\
\hline \multirow{2}{*}{$\begin{array}{l}\text { plus } \\
\text { R } 2 \mathrm{~b} \\
\text { With reversal } \\
\text { agent }\end{array}$} & $\begin{array}{l}\text { Ambulant animal, without observed incoordination, } \\
\text { time of safe release. }\end{array}$ & $49 \pm 15.48$ & $35-70$ & $n=5$ \\
\hline & Total time to recovery & $67 \pm 31.08$ & & \\
\hline
\end{tabular}

\section{Reversal Agent - Atipamezol}

Post atipamezole administration, once the animal reached ambulant position, the recovery period was accompanied by severe motor incoordination.

Time to full recovery comparison, with and without the administration of the alpha-2 antagonist Atipamezol, showed an insignificant difference (p-0.73). 
P value $<0.0001$

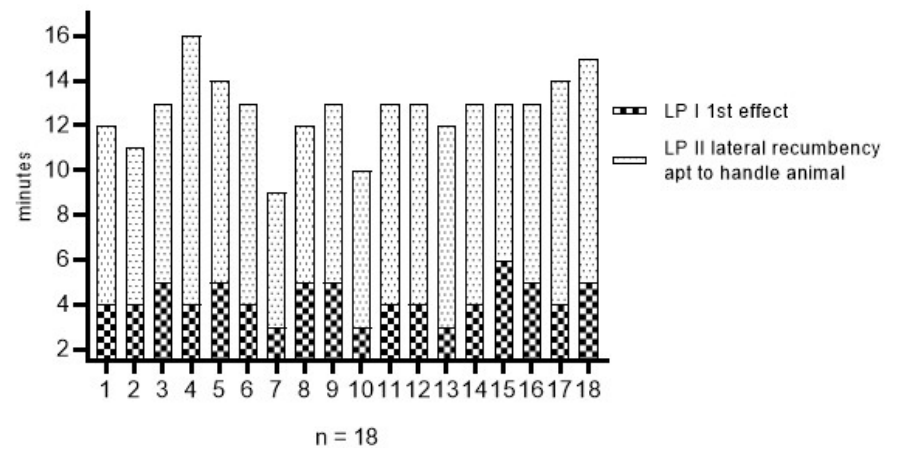

Figure 3. Anesthetic latency effects.

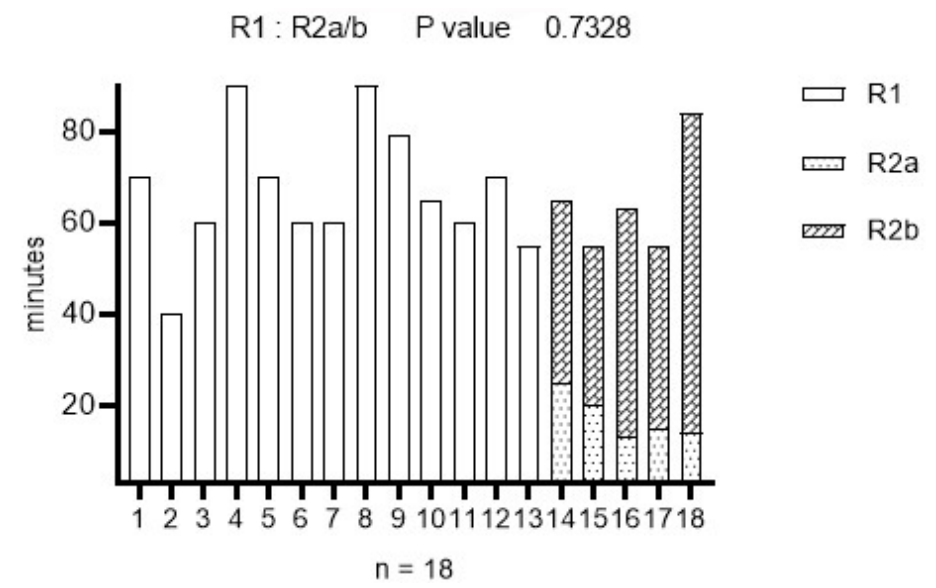

Figure 4. Time to full recovery. Individual data comparison, R1 without, - and R2a/b with anesthetic reversal agent.

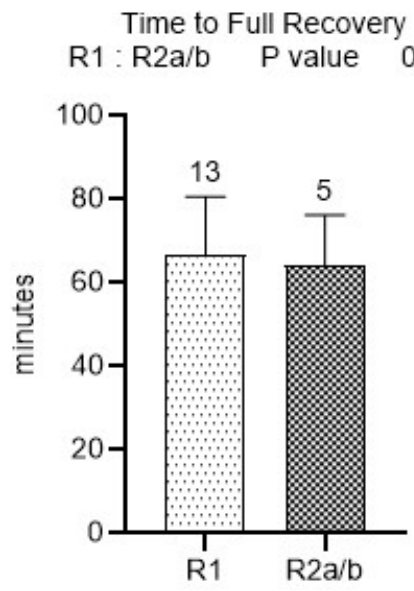

Figure 5. Comparison mean time of recovery times between R1 and R2a/b.

\section{Vital parameters}

Comparing the physiological parameters (Table2; Figure 6), a significant difference was identified for heart rate, respiratory rate, and body temperature. Normal $\mathrm{SpO}_{2}$ could not be collected under non-immobilized conditions.

Vital sign parameter comparison between not sedated animals and animals under anesthetic influence showed significant variations, except peripheral oxygen saturation, which could not be monitored in unsedated animals. 
Table 2. Vital sign values under anesthetic effects and not sedated.

\begin{tabular}{|c|c|c|c|c|}
\hline Vital sign & $\begin{array}{c}\text { Normal } \\
\text { no anesthetic effects }\end{array}$ & $\begin{array}{l}\text { Under Anesthetic } \\
\text { Effects (UAE) }\end{array}$ & $\begin{array}{c}\text { Number } \\
\text { of animals (n) }\end{array}$ & P-value \\
\hline $\begin{array}{l}\text { Heart rate } \\
\text { Bpm* }\end{array}$ & $79.61 \pm$ SD 3.806 & $68.22 \pm$ SD 7.857 & $\mathrm{n}=18$ & 0 \\
\hline $\begin{array}{l}\text { Respiratory } \\
\text { Rate mpm** }\end{array}$ & $39.55 \pm$ SD 3.014 & $32.28 \pm$ SD 3.775 & $\mathrm{n}=18$ & 0 \\
\hline $\begin{array}{l}\text { Body } \\
\text { Temperature }{ }^{\circ} \mathrm{C}\end{array}$ & $34.31 \pm$ SD 0.900 & $36.02 \pm$ SD 1.79 & $\mathrm{n}=18$ & 0.00092 \\
\hline $\begin{array}{l}\text { Peripheral Oxygen } \\
\text { Saturation } \mathrm{SpO}_{2 \%}\end{array}$ & $\mathrm{n} / \mathrm{a}^{* * *}$ & $94 \pm$ SD 2.43 & $\mathrm{n}=18$ & $\mathrm{n} / \mathrm{a}^{* * *}$ \\
\hline $\begin{array}{l}\text { Capillary } \\
\text { refill-time } \\
\text { seconds }\end{array}$ & $\mathrm{n} / \mathrm{a}^{* * *}$ & 3 & $\mathrm{n}=18$ & $\mathrm{n} / \mathrm{a}^{* * *}$ \\
\hline
\end{tabular}

*beats/minute; ${ }^{* *}$ movements/minute; ${ }^{* * *}$ not available
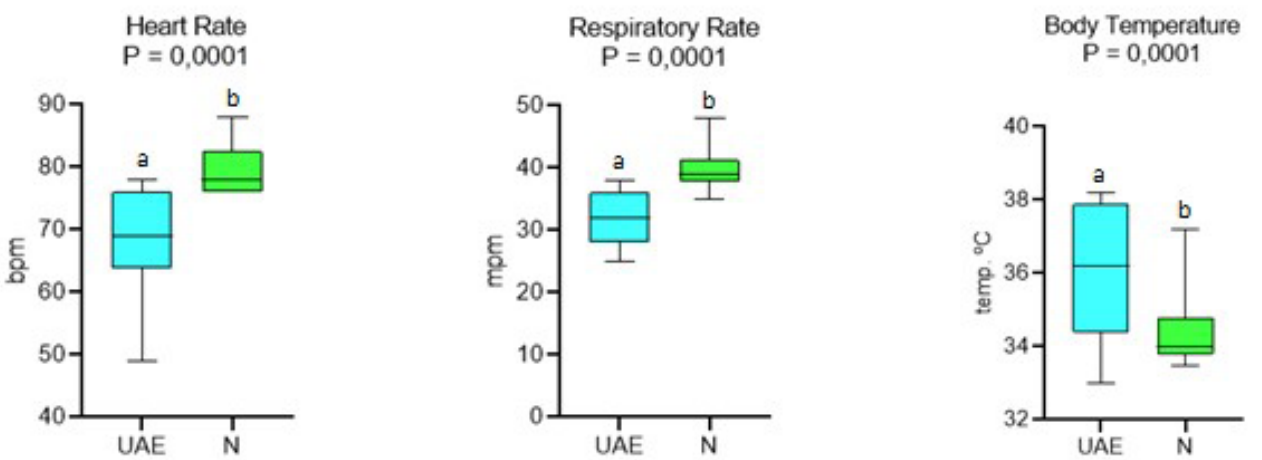

Figure 6. Physiologic parameters. UAE: Under Anesthetic Influence; N: Normal bpm: beats/minute; mpm: movements per minute. Data presented in $\overline{\mathrm{X}} \pm \mathrm{SD}$.

\section{Mortality}

The mortality rate was $5 \%$ (1:18). The cause of death was identified as acute cecal tympany and believed to have been caused by iatrogenic reasons, such as the lack of adequate pre-anesthetic fasting, and anesthetic adverse effect on the gut motility with subsequent difficulty to liberate excessive fermentation gas (Rosenfield et al., 2019a).

\section{Discussion}

Due to the capybara's relative tranquil nature, employing remote injection, was uncomplicated. The specialized darts performed satisfactorily, full drug delivery, no bounce-backs. Being able to rapidly immobilize a capybara means safety for the animal, as vital signs can be monitoring sooner. Nevertheless, as semi-aquatic animals, using water as their principal gateway to safety, prior physical confinement is imperative, thus avoiding any potential death by drowning, and the same holds true for anesthetic recovery.

Prior to establishing an anesthetic field-protocol for remote drug delivery, several anesthetic drug protocols were researched in available literature (Table 3) with emphasis on chemical restraint in capybaras, (Cruz et al., 1998; Góngora et al., 2010; King et al., 2010; Nishiyama, 2006, 2003; Salas et al., 2004).

Besides seeking enhanced anesthetic performance, assisting in collecting semen through urethral catheterization, as reported in several studies (Araújo et al., 2018; Lueders et al., 2012; Pisu et al., 2017), was of great interest, as andrological exams were part of the overall research project. 
Table 3. Anesthetic protocols for capybaras reported in the literature.

\begin{tabular}{|c|c|c|c|c|c|}
\hline Anesthetic agents & $\begin{array}{c}\text { Dosage } \\
\text { respectively }\end{array}$ & $\begin{array}{l}\text { t latency } \\
\text { (min.) }\end{array}$ & $\begin{array}{c}\text { t recovery } \\
(\mathrm{min} .)\end{array}$ & $\begin{array}{l}\mathrm{t} \text { anesthetic } \\
\text { effect (min.) }\end{array}$ & Authors \\
\hline Ketamine - Xylazine & $\begin{array}{c}15 \mathrm{mg} / \mathrm{kg}-1 \mathrm{mg} / \mathrm{kg} \\
10 \mathrm{mg} / \mathrm{kg}- \\
0.5 \mathrm{mg} / \mathrm{kg} \\
10 \mathrm{mg} / \mathrm{kg}- \\
0.5 \mathrm{mg} / \mathrm{kg}\end{array}$ & $\begin{array}{l}7 \pm 1 \\
8.2 \\
\mathrm{n} / \mathrm{a}\end{array}$ & $\begin{array}{c}167 \pm 14 \\
31.7 \\
\mathrm{n} / \mathrm{a}\end{array}$ & $\begin{array}{l}75 \pm 5 \\
95.4 \\
\pm 90\end{array}$ & $\begin{array}{c}\text { Cruz et al. (1998) } \\
\text { Monsalve-Buritica et al. (2013) } \\
\text { Nishiyama (2003) }\end{array}$ \\
\hline Ketamine - Midazolam & $15 \mathrm{mg} / \mathrm{kg}-0.5 \mathrm{mg} / \mathrm{kg}$ & $12 \pm 10$ & $91 \pm 10$ & $8 \pm 1$ & Cruz et al. (1998) \\
\hline $\begin{array}{l}\text { Ketamine } \\
\text { - Medetomidine } \\
\text { - Atipamezol }\end{array}$ & $\begin{array}{c}4 \mathrm{mg} / \mathrm{kg}- \\
40 \mathrm{mcg} / \mathrm{kg}\end{array}$ & $9 \pm 4.73$ & $7 \pm 9 *$ & $\mathrm{n} / \mathrm{a}$ & Salas et al. (2004) \\
\hline Ketamine - Romifidine & $15 \mathrm{mg} / \mathrm{kg}-0.1 \mathrm{mg} / \mathrm{kg}$ & $25 \pm 5$ & $129 \pm 13$ & $25 \pm 5$ & Cruz et al. (1998) \\
\hline $\begin{array}{l}\text { Tiletamine/ } \\
\text { Zolazepam }\end{array}$ & $\begin{array}{r}5.0 \mathrm{mg} / \mathrm{kg} \\
2.3 / 2.3 \mathrm{mg} / \mathrm{kg} \\
5 \mathrm{mg} / \mathrm{kg}\end{array}$ & $\begin{array}{c}7.9 \\
6.6 \\
7\end{array}$ & $\begin{array}{l}72.7 \\
71.4\end{array}$ & 62.5 & $\begin{array}{c}\text { King et al. (2010) } \\
\text { Monsalve-Buritica et al. (2013) } \\
\text { Nishiyama (2003) }\end{array}$ \\
\hline $\begin{array}{l}\text { Tiletamine/ } \\
\text { Medetomidine } \\
\text { - Atipamezol } \\
\text { Tiletamine/ } \\
\text { Medetomidine } \\
\text { - Butorphanol }\end{array}$ & $\begin{array}{r}0.8 / 0.8 \mathrm{mg} / \mathrm{kg} \\
0.008 \mathrm{mg} / \mathrm{kg} \\
0.8 / 0.8 \mathrm{mg} / \mathrm{kg} \\
0.0075 \mathrm{mg} / \mathrm{kg}\end{array}$ & $\begin{array}{c}10.0 \\
8.5\end{array}$ & $\begin{array}{c}49^{*} \\
44.3^{*}\end{array}$ & & King et al. (2010) \\
\hline $\begin{array}{l}\text { Tiletamine/ } \\
\text { Zolazepam } \\
\text { - Levomeproma-zine }\end{array}$ & $\begin{array}{l}5.0 \mathrm{mg} / \mathrm{kg} \\
0.5 \mathrm{mg} / \mathrm{kg}\end{array}$ & 6.8 & 110.1 & 107.3 & Nishiyama (2003) \\
\hline
\end{tabular}

In the present study, the use of a ketamine/dexmedetomidine association, and atipamezole as the alpha-2 antagonist in free-ranging capybaras are being reported for the first time.

Concerning this species, defining the latency period as the time of darting to achieved lateral recumbency, wouldn't be adequate, as the true time (able to handle the animal) required considerably more time. The reason why in this study the latency period was divided into two sub-periods, LP I and LP II. The findings showed a relatively short latency period of $\bar{x}=8$ minutes, compared to 25 minutes (Cruz et al., 1998; Roberto et al., 2018), 10 to 13 minutes (Cruz et al., 1998; King et al., 2010; Salas et al., 2004), and 7.9 to 9.3 minutes (Cruz et al., 1998; Nishiyama, 2006), assuming, in this context, the reported latency meant animals were able to be handled (Table 3).

Total recovery periods, on the other hand, were still lengthy, despite the administration of the alpha-2 agonist reversal, atipamezole, time to full recovery only (free of visible anesthetic effects) was considered for comparison. Results showed no significant difference between the mean $\mathrm{R} 1=66.85$ (no reversal) and a mean $\mathrm{R} 2 \mathrm{a} / \mathrm{b}=64.40$ (with reversal). Contrary to most reported studies, stating faster recoveries when employing atipamezole, although in different species (Arnemo et al., 2005; Granholm et al., 2007; Re et al., 2013; Tsuruga et al., 1999).

Nevertheless, observations made in this study, quality of recovery without a reversal agent suggested being much smoother (less tumbling and falls). An occurrence that perhaps could be linked to residual anesthetic effects of ketamine (Bouts et al., 2010). Another consideration, when working with species that have a higher corporal fat proportion by nature, especially in synanthropic capybaras, that can reach obesity-like status (> 60\% above average weight, \pm 35 - 50kg) (Moreira et al., 2012), compared to none-synanthropics, lipophilic anesthetics might deserve special attention when it comes to action onset, recovery periods, accumulative,- and adverse effects.

The effectiveness and duration of the KD association as chemical restraint and its analgesic properties were satisfactory for in-the-field procedures (min. 50 minutes). However, when applying ear-tags, an additional local analgesic (1mL lidocaine bolus) was needed. 
When comparing normal vital parameters (conscious animal) to parameters under anesthetic effects, significant differences were noticed. Observations on animals under the influence of anesthetics showed bradycardia and respiratory depression:(HR-UAE68 \pm SD = 7.86: HR-N 80 \pm SD 3.81) and (RR-UAE $32 \pm \mathrm{SD}=3.78$ : RR-N $40 \pm \mathrm{SD}=3.01$ ) respectively, which is in agreement with previously reported adverse effects, when using alpha-2 agonists (Arnemo et al., 2005; Granholm et al., 2007; Grayson et al., 2017; Pascoe, 2015).

As before mentioned, employing one of the latest generations of an alpha-2 agonist may aid in pharmacological semen collection. In this study, dexmedetomidine was used with some success in male capybaras.

Concerning adverse effects like hyperthermia under anesthetic influence were recorded through rectal temperature monitoring $(36.0 \pm \mathrm{SD}=1.79$; range: $33-38.2 \mathrm{CO})$, possibility contributed in part by elevated ambient temperatures. Nevertheless, the use of an alpha- 2 agonist is linked to hyperthermia as a collateral effect, as corroborated in studies on several species, including capybaras (Cruz et al., 1998; Grayson et al., 2017; King et al., 2010). When working with hyperthermia-prone capybaras, it is also recommended to have a couple of buckets with water in reach to help control any potential excessive body temperature.

Acute cecal tympany - All anesthetized animals showed varied intensity of abdominal extension (bloat), a condition that rapidly (within a few minutes) can turn into a life-threatening situation, if not identified in time. In one incidence, while continuous monitoring vital signs during recovery, female demonstrated an accelerated heart rate with flat respiration, together with a slight increase of the abdominal volume, - and taut abdominal wall. Shortly thereafter, due to cardiorespiratory arrest, the animal died, despite attempted cardiopulmonary resuscitation. Necropsy performed immediately at the location, an extreme dilation of the cecum, with evidence of ischemic mesentery and intestines was observed. The authors believe that the cause is of iatrogenic nature, brought about by several collective factors, including collateral anesthetic effects, absence of pre-anesthetic fasting, and high-sugary plants for baiting (Rosenfield et al., 2019). Similar observations have been reported in a number of studies and in varied species (Abutarbush et al., 2005; Colorado State University, 2019; Kümper, 1994; Tanila et al., 1993; Torjman et al., 2005; Zullian et al., 2011).

It is important to note that attempting to immobilize free-living animals through long-distance darting comprises many challenges. Especially the accurate estimation of the individual's body weight for anesthetic dosage calculations, which, when miss-calculated, may put the animal in risk of receiving too high of a dose, or the need for additional darting, with the potential risk of overdosing. Particularly true for synanthropic capybaras, that may reach body weights of $60 \%$ higher, with a maximum reported 105kg (pers. comm., 2018), compared to their non-synanthropic counterparts, weighing an average of 40 - 50kg (Moreira et al., 2012).

Using adequate equipment, combined with the competent use of Remote Drug Delivery System (RDDS), has shown to provide overall better project execution, and more importantly, is safer for the animals. Different from alternative capture methods, as described by (Salas et al., 2004), in this case, using a lariat. All animals captured by lasso demonstrated what can only be interpreted as severe stress, with difficulties of movement, hyperventilation, and some reported deaths.

When working with capybara, the use of a corral for physical restraint is fundamental for the safety of the animals, avoiding escapes and any potential death by drowning of sedated individuals (Salas et al., 2004). In addition, one aspect to consider that can bring great benefits, if time and logistics permits, is to apply classic-conditioning of target individuals. Allowing to be called and herded into the corral voluntarily, facilitating time-independent, frequent and selective capture (versus aleatory success), provoking less capture-induced stress, reducing the risk of injury (even death), while requiring lesser amounts of anesthetics, producing smoother recovery, and improving overall team safety. Furthermore, it allows conducting health exams and vital parameter evaluation, such as auscultation for the heart, - respiratory rate, and body temperature (Rosenfield \& Schilbach Pizzutto, 2019).

Regarding the baiting methods for capybaras, as before mentioned, using plants or fruits with high sugar content as bait is certainly a great tool to lure, however, it is also the one with a certain risk if used excessively, as it can easily provoke a situation of acute cecal tympany, a life-threatening emergency in capybaras, whose onset is not readily recognized, since signs are rather subtle, like the slight loss of visible lower rib-cage contour due to abdominal dilation. 
Only in anticipation and through constant monitoring heart rate, blood pressure, and respiratory rate, and percussion/palpation of the abdominal wall is it possible to identify tympany in time. Therefore, it is crucial to use sugary plants or fruits in very small quantities, just enough to draw attention (Rosenfield et al., 2019). Alternatively, less sugar-containing corn and banana leaves work quite well and are safer.

\section{Conclusion}

For the present study on free-living capybaras and intended procedures, the anesthetic protocol of a ketamine/dexmedetomidine association performed adequality. The use of an alpha- 2 agonist reversal agent did not lessen significantly the recovery period. The use of specialized RDDS provided satisfactory drug delivery quality. Use of blowgun in the field is discouraged.

\section{References}

Abutarbush, S. M., Carmalt, J. L., \& Shoemaker, R. W. (2005). Causes of gastrointestinal colic in horses in western Canada: 604 cases (1992 to 2002). The Canadian Veterinary Journal. La Revue Veterinaire Canadienne, 46(9), 800-805. PMid:16231649.

Araújo, G. R., Paula, T. A. R., Deco-Souza, T., Morato, R. G., Bergo, L. C. F., Silva, L. C., Costa, D. S., \& Braud, C. (2018). Comparison of semen samples collected from wild and captive jaguars (Panthera onca) by urethral catheterization after pharmacological induction. Animal Reproduction Science, 195,1-7.http://dx.doi.org/10.1016/j. anireprosci.2017.12.019. PMid:29935916.

Arnemo, J. M., Storaas, T., Khadka, C. B., \& Wegge, P. (2005). Use of medetomidine-ketamine and atipamezole for reversible immobilization of free-ranging hog deer (Axis porcinus) captured in drive nets. Journal of Wildlife Diseases, 41(2), 467-470. http://dx.doi.org/10.7589/0090-3558-41.2.467. PMid:16107687.

Bouts, T., Harrison, N., Berry, K., Taylor, P., Routh, A., \& Gasthuys, F. (2010). Comparison of three anaesthetic protocols in Bennett's wallabies (Macropus rufogriseus). Veterinary Anaesthesia and Analgesia, 37(3), 207-214. http://dx.doi.org/10.1111/j.1467-2995.2009.00523.x. PMid:20230552.

Cizauskas, C. A. (2008). Zoo animal \& wildlife immobilization and anesthesia. Journal of Wildlife Diseases, 44(2), 528-530. http://dx.doi.org/10.7589/0090-3558-44.2.528.

Colorado State University. (2019). Ruminal Tympany. Fort Collins. Retrieved in 1 December 2019, from http:// www.vivo.colostate.edu/hbooks/pathphys/digestion/herbivores/tympany.html

Cruz, M. L., Luna, S. P. L., Moura, C. A., Castro, G. B., Neto, T., José, F., \& Nishida, S. M. (1998). Anaesthetic techniques in capybaras (Hydrochoerus hydrochaeris, Linné). Ciência Rural, 28, 411-415. http://dx.doi.org/10.1590/ S0103-84781998000300010.

Ferraro, M. A. R., Molina, C. V., Gris, V. N., Kierulff, M. C. M., Bueno, M. G., \& Cortopassi, S. R. G. (2019). Early reversal of ketamine/dexmedetomidine chemical immobilization by atipamezole in golden-headed lion tamarins (Leontopithecus chrysomelas). Journal of Medical Primatology, O(6), 351-356. http://dx.doi.org/10.1111/ jmp.12429. PMid:31194266.

Góngora, A., Murillo, R., Rodríguez, J., Rincón-Aranguri, M., \& Morales, R. (2010). Obtención y Evaluación de las Características Seminales del Chigüiro (Hydrochoerus hydrochaeris). Memorias Conferencia Internacional de Medicina y Aprovechamiento de Fauna Silvestre Exótica, 6, 15-23.

Granholm, M., McKusick, B. C., Westerholm, F. C., \& Aspegren, J. C. (2007). Evaluation of the clinical efficacy and safety of intramuscular and intravenous doses of dexmedetomidine and medetomidine in dogs and their reversal with atipamezole. The Veterinary Record, 160(26), 891-897. http://dx.doi.org/10.1136/vr.160.26.891. PMid:17602104.

Grayson, K., Tobin, A. E., Lim, T. K., Reid, D. E., \& Ghani, M. (2017). Dexmedetomidine-associated hyperthermia: a retrospective cohort study of intensive care unit admissions between 2009 and 2016. Anaesthesia and Intensive Care, 45(6), 727-736. http://dx.doi.org/10.1177/0310057X1704500613. PMid:29137584.

Herrera, E. A., \& Macdonald, D. W. (1989). Resource utilization and territoriality in group-living Capybaras (Hydrochoerus hydrochaeris). Journal of Animal Ecology, 58(2), 667-679. http://dx.doi.org/10.2307/4855.

King, J. D., Congdon, E., \& Tosta, C. (2010). Evaluation of three immobilization combinations in the capybara (Hydrochoerus hydrochaeris). Zoo Biology, 29(1), 59-67. http://dx.doi.org/10.1002/zoo.20269. PMid:19645047.

Kümper, H. (1994). New therapy for acute abomasal tympany in calves. Tierärztliche Praxis, 22(1), 25-27. PMid:8165656.

Lueders, I., Luther, I., Scheepers, G., \& van der Horst, G. (2012). Improved semen collection method for wild felids: urethral catheterization yields high sperm quality in African lions (Panthera leo). Theriogenology, 78(3), 696-701. http://dx.doi.org/10.1016/j.theriogenology.2012.02.026. PMid:22538007.

Mones, A., \& Ojasti, J. (1986). Hydrochoerus hydrochaeris. Mammalian Species, 1(264), 1-7. http://dx.doi. $\operatorname{org} / 10.2307 / 3503784$. 
Monsalve-Buritica, S., Rojano-Bolano, C., \& Carrascal-Velasquez, J. C. (2013). Comparison of two anesthetic protocols in wild capybaras (Hydrochoerus hydrochaeris isthmius) in the department of Córdoba, Colombia. Veterinária e Zootecnia, 7(1), 90-99.

Moreira, J. R. (2013). Capybara: biology, use and conservation of an exceptional neotropical species (1st ed.). New York: Springer. http://dx.doi.org/10.1007/978-1-4614-4000-0.

Moreira, J. R., Ferraz, K. M. P. M. B., Herrera, E. A., \& MacDonald, D. W. (2012). Capybara:Biology, use and conservation of an exceptional neotropical species. New York, NY: Springer Science \& Business Media.

Nishiyama, S. M. (2006). Associação cetamina-xilazina, tiletamina-zolazepam e tiletaminazolazepamlevomepromazina na anestesia de Capivara (Hydrochoerus hydrochaeris). Revista Ceres, 53(307), 406-412.

Nishiyama, S. M. (2003). Associação cetamina-xilazina, tiletamina-zolazepam, e tiletamina-zolazepamlevomepromazina na anestesia de capivara (Hydrochoerus hydrochaeris). Revista Ceres, 53(307), 406-412.

Pascoe, P. J. (2015). The cardiopulmonary effects of dexmedetomidine infusions in dogs during isoflurane anesthesia. Veterinary Anaesthesia and Analgesia, 42(4), 360-368. http://dx.doi.org/10.1111/vaa.12220. PMid:25082327.

Pisu, M. C., Ponzio, P., Rovella, C., Baravalle, M., \& Veronesi, M. C. (2017). Usefulness of an injectable anaesthetic protocol for semen collection through urethral catheterisation in domestic cats. Journal of Feline Medicine and Surgery, 19(10), 1087-1090. http://dx.doi.org/10.1177/1098612X16679589. PMid:27856784.

Re, M., Blanco-Murcia, F. J., San Miguel, J. M., \& Gómez de Segura, I. A. (2013). Reversible chemical restraint of free-range cattle with a concentrated combination of tiletamine-zolazepam, ketamine, and detomidine. Canadian Journal of Veterinary Research, 77(4), 288-292. PMid:24124271.

Roberto, G. V., Tonon, L. V., Oleskovicks, N., \& Moraes, A. N. (2018, September 12-13). Avaliação da Anestesia intravenosa em procedimentos de esterilização no manjeo reprodutivo de Capivaras (Hydrochaeris hydrochaeris) de vida livre no município de lages. In 280 Seminário de Iniciação Científica (pp. 1-2). Santa Catarina: Universidade do Etado de Santa Catarina.

Rosenfield, D., Ferraro, M. A., Yanai, P. R., Igayara, C., \& Schilbach Pizzutto, C. (2019a). Acute Cecal tympany during chemical restraint in free-ranging Capybara (Hydrochoerus Hydrochaeris) - Iatrogenic Cause and Treatment. Brazilian Journal of Veterinary Pathology, 12(3), 117-122. http://dx.doi.org/10.24070/bjvp.1983-0246.v12i3p117-122.

Rosenfield, D. A., Nichi, M., Losano, J. D. A., Kawai, G., Leite, R. F., Acosta, A. J., Baquero, O. S., \& Pizzutto, C. S. (2019b). Field-testing a single-dose immunocontraceptive in free-ranging male capybara (Hydrochoerus hydrochaeris): Evaluation of effects on reproductive physiology, secondary sexual characteristics, and agonistic behavior. Animal Reproduction Science,209, 106148. http://dx.doi.org/10.1016/j.anireprosci.2019.106148. PMid:31514916.

Rosenfield, D. A., \& Schilbach Pizzutto, C. (2019). Positive-reinforcement strategies to reduce Capture-Stress in Capybaras - Manuscript submitted for publication. Acta Scientiarum, 41:1-12.

Salas, V., Pannier, E., Galíndez-Silva, C., Gols-Ripoll, A., \& Herrera, E. A. (2004). Methods for Capturing and Marking Wild Capybaras in Venezuela. Wildlife Society Bulletin, 32, 202-208.

Spinosa, H. S., Górnik, S. L., \& Bernardi, M. M. (2011). Farmacologia aplicada à medicina veterinária (6. ed.). Rio de Janeiro: Guanabara Koogan.

Tanila, H., Kauppila, T., \& Taira, T. (1993). Inhibition of intestinal motility and reversal of postlaparotomy ileus by selective $\alpha 2$-adrenergic drugs in the rat. Gastroenterology, 104(3), 819-824. http://dx.doi.org/10.1016/00165085(93)91018-D. PMid:8095034.

Torjman, M. C., Joseph, J. I., Munsick, C., Morishita, M., \& Grunwald, Z. (2005). Effects of Isoflurane on gastrointestinal motility after brief exposure in rats. International Journal of Pharmaceutics, 294(1-2), 65-71. http://dx.doi. org/10.1016/j.jpharm.2004.12.028. PMid:15814231.

Tsuruga, H., Suzuki, M., Takahashi, H., Jinma, K., \& Kaji, K. (1999). Immobilization of Sika Deer with Medetomidine and Ketamine, and Antagonism by Atipamezole. Journal of Wildlife Diseases, 35(4), 774-778. http://dx.doi. org/10.7589/0090-3558-35.4.774. PMid:10574539.

Wellington, D., Mikaelian, I., \& Singer, L. (2013). Comparison of Ketamine-Xylazine and Ketamine-Dexmedetomidine anesthesia and intraperitoneal tolerance in rats. Journal of the American Association for Laboratory Animal Science, 52(4), 481-487. PMid:23849447.

West, G. D., Heard, D. J., \& Caulkett, N. (2007). Zoo animal and wildlife immobilization and anesthesia (1st ed.) Ames, Iowa: Blackwell Publishing. http://dx.doi.org/10.1002/9780470376478.

Zullian, C., Menozzi, A., Pozzoli, C., Poli, E., \& Bertini, S. (2011). Effects of a2-adrenergic drugs on small intestinal motility in the horse: An in vitro study. Veterinary Journal (London, England), 187(3), 342-346. http://dx.doi. org/10.1016/j.tvjl.2009.12.015. PMid:20093057. 